\title{
Current problems in China's manufacturing and countermeasures for industry 4.0
}

\author{
Lei Feng $^{1 *}$, Xuehui Zhang ${ }^{1}$ and Kaige Zhou $^{2}$
}

\begin{abstract}
Industry 4.0 was proposed by Germany, which will bring a revolution in manufacturing. How does China's manufacturing sector deal with this revolution? The key is to identify problems and provide solutions. Based on the analysis of statistical data and the qualitative analysis, the paper carries out an in-depth analysis of current situation of China's manufacturing. Then, main problems in China's manufacturing industry were analyzed. Finally, the paper puts forward concrete countermeasures for China's manufacturing sector. The countermeasures were as follows: pushing technological innovation by strengthening cooperation of official-industry-university-research-customer, developing manufacturing technology criteria in line with international practice, setting up the intelligent key projects and launching pilot project, and constructing network infrastructure. China's manufacturing industry is still not very advanced, so it is necessary to seize the opportunity of industry 4.0. The countermeasures proposed in this paper can be used as suggestions for China's manufacturing sector in the Industry 4.0 era.
\end{abstract}

Keywords: Industry 4.0, Manufacturing sector, Transformation, Intelligent manufacturing

\section{Introduction}

The concept of "Industry 4.0" was widely recognized in the world after its presentation in the 2011 Hannover Industrial Expo. Industry 4.0 is now commonly used to refer to the development of "cyber-physical systems" (CPS) and dynamic data processes that use massive amounts of data to drive smart machines [1]. The development of manufacturing industry is divided into four periods by Germany. The first industrial revolution (industry 1.0): steam-driven equipment was widely put into production. The second industrial revolution (industry 2.0): power-driven equipment was largely used and the emergence of labor division. The third industrial revolution (industry 3.0): automation of the manufacturing process was realized by electronic and factory technology. The fourth industrial revolution (industry 4.0): intelligent industry emergences based on Cyber Physical Systems (CPS). The fourth industrial revolution is called as Industry 4.0 by Germany that is the intelligence manufacturing [2]. Industry 4.0 is dominated by intelligent manufacturing. Countries all over the world have

\footnotetext{
* Correspondence: ttfff01@126.com

${ }^{1}$ School of Economics and Management, China University of Petroleum, Qingdao, China

Full list of author information is available at the end of the article
}

launched policies to increase investment to promote the intelligent manufacturing, and strive to achieve transformation and upgrading of their manufacturing industries. China, as an important manufacturing country in the world, is no exception.

According to the analysis, this paper found many problems in China's manufacturing detailed in the following: inefficient unit labor output, imperfect standard system of industrialization, weak innovative capacity and lack of core talents, poor construction of digital infrastructure, high energy consumption, high pollution, and low added value. The paper also put forward some countermeasures.

\section{Methodology}

The data are mainly from National Bureau of Statistics, International Labor Organization, and China's Internet Network, which are the official website, so the validity of the data is guaranteed. The overview of China's manufacturing industry is given from different viewpoint through data analysis and the qualitative analysis.

\subsection{From the viewpoint of outputs}

The production of China's manufacturing industry is over 110,000 billion yuan in 2009 and is increasing year after year. The outputs of manufacturing industry 
accounts for about 30\% of GDP from 2009 to 2015 (as shown in Table 1). Manufacturing industry occupies an important position in the national economy of China and is one of the pillar industry in China.

\subsection{From the viewpoint of employment}

The manufacturing industry is a major industry to absorb the labor in China. Figure 1 shows that the proportion of employment of manufacturing industry in the total employment from 2009 to 2016. In 2013, the proportion reaches $29 \%$, a relatively high level. In general, the employment of manufacturing industry accounts for about $28 \%$.

\subsection{From the viewpoint of market}

With the rapid development of China's economy and urban-rural integration, consumer market has become more and more extensive. Compared with the mature market of developed countries, China's domestic market has just started, and there is a wider space for development in the future. Compared with other developing countries, the domestic purchasing power of China is higher. The level of disposable income can reflect the purchasing power to a certain extent. Figure 2 presents the disposal income of urban and rural residents. From 2010 to 2016, no matter the disposable income of urban residents or the disposable income of rural residents is significantly improved. So, there has a huge potential domestic market in China's manufacturing industry, which is a huge advantage.

\subsection{From the viewpoint of foreign investment and investment abroad}

Figure 3 presents the trend of foreign investment and investment abroad in China's manufacturing industry. From Fig. 3, it can be observed that foreign investment has been decreasing year by year. That means that China's manufacturing industry had become less attractive. By contrast, investment abroad has increasing year by year. That means that China's manufacturing industry is becoming more and more closely linked with foreign countries.

Table 1 The proportion of manufacturing outputs in GDP

\begin{tabular}{llll}
\hline Year & $\begin{array}{l}\text { Manufacturing } \\
\text { output (billion yuan) }\end{array}$ & $\begin{array}{l}\text { GDP } \\
\text { (billion yuan) }\end{array}$ & Proportion \\
\hline 2009 & $110,118.5$ & $349,081.4$ & 0.32 \\
2010 & $130,282.5$ & $413,030.3$ & 0.32 \\
2011 & $153,062.7$ & $489,300.6$ & 0.31 \\
2012 & $169,806.6$ & $540,367.4$ & 0.31 \\
2013 & $181,867.8$ & $595,244.4$ & 0.31 \\
2014 & $195,620.3$ & 643,974 & 0.3 \\
2015 & $202,420.1$ & $689,052.1$ & 0.29 \\
\hline
\end{tabular}

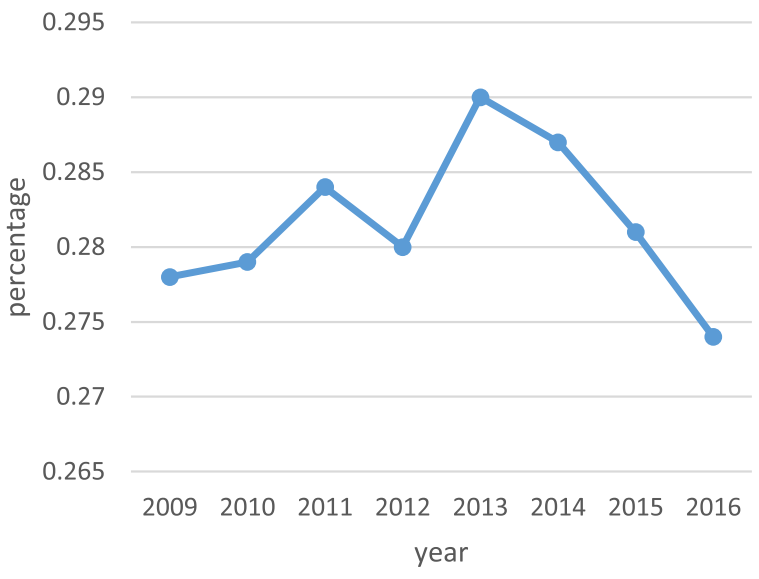

Fig. 1 The proportion of employment of the manufacturing sector in total employment

\section{Results and discussion}

Although China's manufacturing industry has made considerable progress and has strong support for China's development, there are still many problems. In the following section, the problems in China's manufacturing industry are discussed and the countermeasures are provided.

\subsection{The problems of China's manufacturing industry under the background of industry 4.0}

3.1.1 Inefficient unit labor output

Compared with developed countries, unit labor output in China's manufacturing industry is inefficient because of the lack of manufacturing technology. As shown in Table 2, although the unit labor output of China is increasing year by year, there is still a big gap between China and the developed countries. It can be seen that the unit labor output of China is seriously low. China should vigorously develop science and technology and take the opportunity of industrial 4.0 to improve unit labor output.

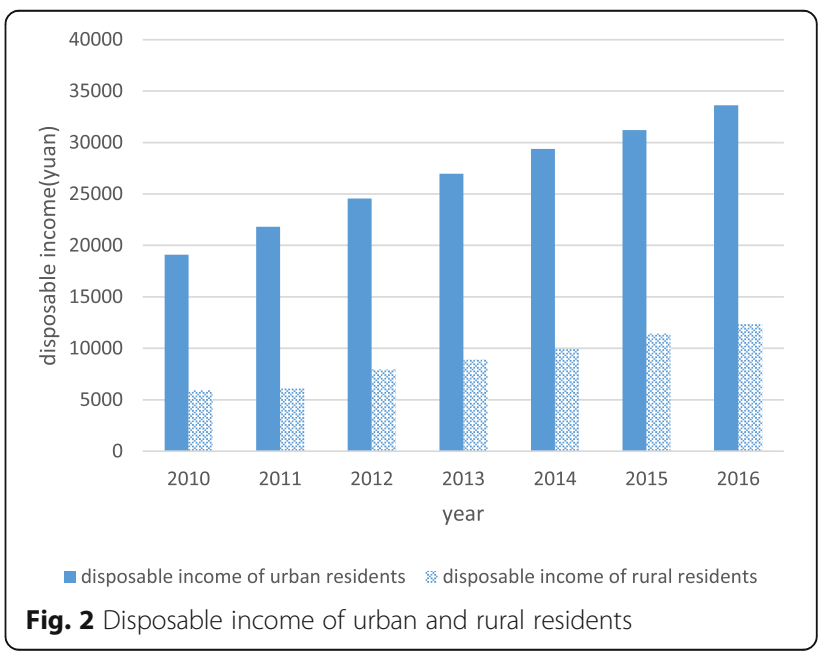




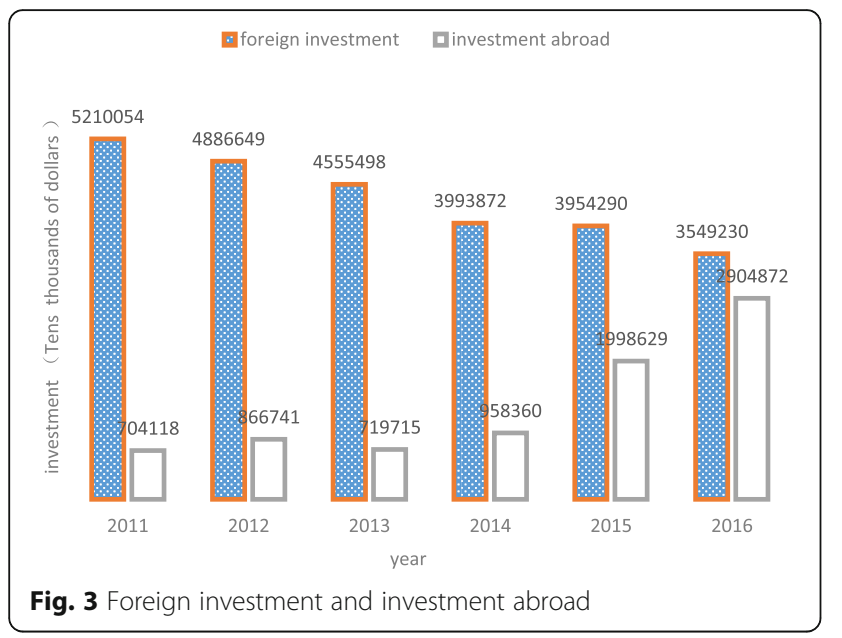

\subsubsection{Imperfect standard system of industrialization}

In order to realize the industry 4.0 , a set of standard system needs to be established, which can make network connection and information integration between the different companies possible. Now, China still lag behind in safeguard measures, long-term mechanism of manufacturing industry transformation and upgrading, intellectual property protection system, personnel training system, quality inspection system, and comprehensive management and control system.

\subsubsection{Weak innovative capacity and lack of core talents}

The capacity of scientific and technological innovation is the driving force to a country's economy and also an important standard to measure the comprehensive ability of one country. Innovative capacity is closely related to $R \& D$ investment. In terms of the proportion of $R \& D$ to GDP (shown in Table 3), China is still lagging behind the world average. Now, the competition between the market and the economic strength is inclined in core technology and the innovative ability. Compared with the major manufacturing countries in the world, China's scientific and technological innovation ability and core technology are obviously in a disadvantaged position. Under the background of industry 4.0, the linkage between people, machine, and market is more important,

Table 2 Unit labor output (at constant prices in 2005, US\$/person)

\begin{tabular}{lllllll}
\hline Year & World average & USA & Japan & Eurozone & India & China \\
\hline 2009 & 16,963 & 92,560 & 70,477 & 64,946 & 2503 & 4674 \\
2010 & 17,449 & 95,069 & 73,631 & 66,586 & 2731 & 5146 \\
2011 & 17,711 & 95,724 & 74,108 & 67,559 & 2909 & 5586 \\
2012 & 17,883 & 96,062 & 75,510 & 67,083 & 3024 & 5990 \\
2013 & 18,107 & 97,748 & 75,958 & 67,164 & 3189 & 6423 \\
2014 & 18,285 & 98,116 & 75,376 & 67,867 & 3370 & 6866 \\
2015 & 18,487 & 98,990 & 76,068 & 68,631 & 3559 & 7318 \\
\hline
\end{tabular}

Note: The Eurozone data is the average of 19 member states
Table 3 R\&D cost and proportion in GDP

\begin{tabular}{llllll}
\hline Year & 2012 & 2013 & 2014 & 2015 & 2016 \\
\hline $\begin{array}{l}\text { R\&D cost } \\
\text { (billion yuan) }\end{array}$ & 10,298 & 11,847 & 13,016 & 14,170 & 15,500 \\
GDP (billion yuan) & $540,367.4$ & $595,244.4$ & 643,974 & $689,052.1$ & $744,127.2$ \\
Proportion (\%) & 1.91 & 1.99 & 2.02 & 2.06 & 2.08 \\
\hline
\end{tabular}

which requires higher manufacturing technology and more core talents.

\subsubsection{Poor construction of digital infrastructure}

China's network system has been initially built, but the popularity and speed of network are far behind that of developed countries such as Germany. As shown in Fig. 4 , there is a big difference between urban and rural areas on internet popularity. According to statistics, by the end of 2016, the difference in the popularity of the Internet between urban and rural areas reached $45.2 \%$. Due to convenient transportation and better infrastructure, urban areas have relative advantages in network updating and equipment maintenance, while the network in rural areas is basically at a standstill. Seventy percent of the manufacturing enterprises in China are distributed in the rural areas, so the network cannot meet the requirements of the industrial 4.0 which should be safe, fast, efficient, and real-time.

\subsubsection{High energy consumption, high pollution, and low added value}

Table 4 provides energy consumption in the manufacturing industry and the proportion of energy consumption in the manufacturing industry to total energy consumption. The proportion is relatively high and there is an increasing trend in recent years. There is a severe situation of high consumption, high pollution, but low added value in China. It does not fit in with economic sustainable

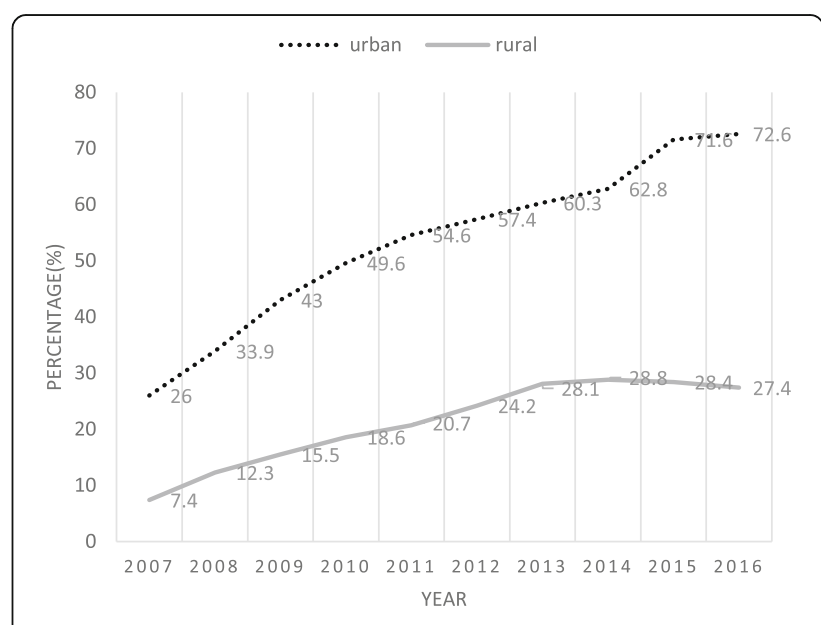

Fig. 4 Internet popularity in urban and rural areas 
Table 4 Energy consumption in the manufacturing industry

\begin{tabular}{lll}
\hline Year & $\begin{array}{l}\text { Total energy consumption in } \\
\text { the manufacturing industry } \\
(10,000 \text { tons of standard coal) }\end{array}$ & $\begin{array}{l}\text { The proportion of energy } \\
\text { consumption in manufacturing } \\
\text { industry to total energy } \\
\text { consumption }\end{array}$ \\
\hline 2009 & $180,595.97$ & 0.54 \\
2010 & $188,497.85$ & 0.52 \\
2011 & $200,403.37$ & 0.52 \\
2012 & $205,667.69$ & 0.51 \\
2013 & $239,053.4$ & 0.57 \\
2014 & $245,051.39$ & 0.58 \\
2015 & $244,919.56$ & 0.57 \\
\hline
\end{tabular}

development and will greatly weaken the competitiveness of Chinese products and make our products lose its advantages in terms of price and technology.

\subsection{Countermeasures in manufacturing industry}

In the face of above problems, whether China's manufacturing industry can achieve leapfrog development is a major issue. Fortunately, Germany can provide some references in theory and practice of the industrial 4.0 for our country.

\subsubsection{Strengthening cooperation between government, industry, university, research unit, and customer}

Germany's industry 4.0 is proposed mainly by the German Academy of engineering, the Association of Fraunhof, and the SIEMENS [3]. The members of the working group are composed of representatives from the government, industry, university, research unit, and customer. Many research teams and platform are set up, one of which is the Fourth Industrial Revolution office established by German Information Technology Communications Association of New Media, the German Import Equipment Manufacturing Industry Association, and the German Electronic and Electrical Industry Association. The office is set up to attract and make full use of and integrate resources to the development of industry 4.0.

The industry 4.0 systems with the Chinese characteristics are still at an early stage, which urgent need to learn from Germany. On the one hand, the government should provide financial and policy support for the $R \& D$ alliances and different types of industry based on the cooperation between industry, university, research unit, and customer [4]. On the other hand, a pilot program can be carried out in some industries and some key technology areas. A variety of alliance systems can be organized by leading enterprises, research institutions, and universities with strong research capabilities. The alliance should fully mobilize the resources, encourage the development and promotion of key technologies, make the manufacturing industry more intelligent, and promote the establishment and development of talent system.

\subsubsection{Constructing and implementing technological standards for intelligent manufacturing}

To ensure that industry 4.0 can be successfully achieved, Germany has made detailed plans and put forward the "standardization" which is placed in the first place. It was also advocated that the independent working team should be set up to deal with the problems of standardization and reference frame. In addition, in order to highlight the importance of standardization, Germany published the world's first standardized road map of industry 4.0 in December 2013. Standardization make it possible to interconnect and intercommunicate between people, machines and resources. The data exchange, identification and maintenance between the terminal devices and software must be based on this standardized system.

At present, China's manufacturing industry has different levels in informationization and automatization [5]. There are so many types of industrial intelligent software, which make production equipment and facilities incompatible with each other. Many enterprises and industry associations have tried to put forward technical standard systems, but they were not widely recognized by the market because of their lack of sufficient technology and call capacity of market. So, the government should plays the main function to encourage and guide large-scale enterprises to set technical standards of intelligent manufacturing, to activate market demand, and to attract social forces to push technological innovation.

The standards of intelligent manufacturing technology include two aspects. One is the standards of connection between domestic enterprises; the other is the standards to integrate with the world. In order to realize "industrial 4.0," the China must actively participate in the international division of labor, and participate in the development of international technology standards. Only in this way can China have a say on the competition in manufacturing industry.

\subsubsection{Cultivating manufacturing talents}

In Germany, vocational education has been very popular. According to statistics, there are nearly $80 \%$ young people in Germany accept the vocational education which is the successful mode. Vocational schools can provide a large number of outstanding industrial workers. It makes the industry 4.0 easily achieved in Germany. The industrial 4 . 0 has made a profound change in the man-machine relationship that the machine will gradually replace the human. The simple mechanical work will be replaced by precision and intellect work with higher value added. At 
the same time, it sets higher requirements for workers' knowledge and skills.

So, China should pay more attention to the personnel training and actively promote vocational education, improve training system, update training knowledge in time, provide retraining for existing personnel, and build the human resources advantages in knowledge and skills.

\subsubsection{Constructing network infrastructure}

The ideal state for industry 4.0 is that the freight car is directly connected to the production machine through the network. When the freight car is ready to carry goods, the system will automatically convey this information to the production machine [6]. Then production machine will be prepared for production in advance, as a result, the production time will be optimal and the waiting time will be shorter. Hanno Kempemann, the expert in digital economy and regional analysis from Cologne institute of economic research (Germany), once said: "The network speed of 50 megabits per second (50mbit/ s) recommended in the development of digitalization is not enough. $50 \mathrm{mbit} / \mathrm{s}$ may be able to meet the needs of 2018 which is the first year of digital development. The speed of the network may reach 100 megabits per second in 2020. At that time, with the growing demand of information from various industries, the increase of data quantum is very fast."

There are higher requirements to network infrastructure in China. China must pay high attention to and strengthen the network infrastructure construction [7]. China should increase network speed and at the same time narrow the gap between urban and rural in network infrastructure. Ultimately, China can realize that the information between enterprises no matter where they are transfer rapidly.

\subsubsection{Setting up major intelligent projects [8]}

The intelligent technology is now applied in a large variety of manufacturing areas which becomes the trend of the world's manufacturing industry by replacing the existing production technologies. Intelligent production will inevitably replace the traditional production. The developed countries including Germany are preparing for the trend by starting the major projects.

China has established a relatively complete industrial system in some fields, such as 3D printing, CNC machine tools, and intelligent measurement and control. However, compared with the other country, China still takes the simple and extensive reproduction as the main idea and way in manufacturing industry. It is an arduous and difficult task that China's traditional manufacturing industry be upgraded with new concept of intelligent manufacturing.
In order to promote the transformation of manufacturing from traditional production to intelligent production, the following measures can be carried out. The first is to focus on the development of intelligent robot, and to develop core techniques of integration, design and manufacture of the intelligent equipment system. The second is to popularize digital factory. Pilot work can be initially carried out in sub-sectors and sub-region. Pilot enterprises should be supported to gradually set up digital manufacturing demonstration factory. Then, the digital factory will be carried out over the whole country. The third is to upgrade the capabilities of Chinese manufacturing enterprises by application of big data and choosing the leading enterprises. Setting up major intelligent projects is an essential step of wide application of intelligent technology.

\section{Conclusions}

It takes not overnight but a long time to transform and upgrade China's manufacturing industry. What Chinese manufacturing sector needs to do now is to overcome the problems and gradually move towards industrial 4.0. China's intelligent industry is a long and arduous task which needs the various participations. China's manufacturing sector can build the platform consist of government, industry, university, research unit, and customer to promote technological innovation in an all-round way. The industry 4.0 era will make the relationship between countries and the world becoming more and more closely linked, and their inter-dependence is strengthening. Therefore, it is important to establish the manufacturing technological standards in line with the world's standards. In industry 4.0 era, the requirement for the network is higher. So, China must build network infrastructure to meet the requirement. To achieve the industrial transformation and upgrading is a huge systematic project. So, it is necessary to set up major intelligent projects and carry out pilot work which can lay a good foundation for the industrial transformation and upgrading. Ultimately, all competition depends on the talent competition, so talent in manufacturing industry occupies an important position absolutely. China's manufacturing sector must build the Personnel-Training system to cultivate intelligences who meet the needs of industry 4.0. Only in the above discussed way can China occupy a place in the world manufacturing industry and achieve from big manufacturing country to powerful one.

Of course, there are just several but not all the problems and countermeasures. Even if these measures are implemented, the road to manufacturing power is also not easy. In the future, China's manufacturing sector should keep an eye on the emerging problems all the time and take good countermeasures in time. 


\section{Availability of data and materials}

The data in Table 1, Fig. 1, Fig. 2, Fig. 3, and Table 4 are from China Statistical Yearbook $(2010,2011,2012,2013,2014,2015,2016,2017)$, National Bureau of Statistics of China.

The data in Table 2 are from International Labor Organization.

The data in Table 3 are from National Bureau of Statistics of China.

The data in Fig. 4 are from statistical report on the development of China's Internet Network (2017).

\section{Authors' contributions}

$L F$ is the main writer of this paper. She proposed the main idea, completed the first draft of the paper, and amend and review papers. XZ analyzed the current situation of China's manufacturing industry and gave some important suggestions for the Part 4. KZ collected the data of Fig. 1, Fig. 2, and Fig. 3 and gave some important suggestions for the Part 5. All authors read and approved the final manuscript.

\section{Competing interests}

The authors declare that they have no competing interests.

\section{Publisher's Note}

Springer Nature remains neutral with regard to jurisdictional claims in published maps and institutional affiliations.

\section{Author details}

'School of Economics and Management, China University of Petroleum Qingdao, China. ${ }^{2}$ Guangzhou University of Chinese Medicine, Guangzhou, China.

Received: 7 March 2018 Accepted: 18 April 2018

Published online: 02 May 2018

\section{References}

1. R Strange, A Zucchella, Industry 4.0, global value chains and international business. Multinatl. Bus. Rev. 25(3), 174-184 (2017).

2. H Lasi, P Fettke, H-G Kemper, T Feld, M Hoffmann, Industry 4.0. Business \& Information Systems Engineering. Business \& Information Systems Engineering, 6(4), 239-242 (2014).

3. P LI, Y Liu, The development of scientific and technological research system in German and its implications to the innovation base construction in China. Sci Manag Res 2, 52-57 (2011).

4. $\mathrm{GL} X \mathrm{Xu}, \mathrm{GQ}$ Lin, New thing on the transformation and upgrading of traditional manufacturing industry under the background of industry 4.0 Shanghai. J. Econ. 10, 107-113 (2015).

5. AJ Shao, The study on comparison between 'China's Manufacture $2015^{\prime}$ \& 'Industry 4.0' and countermeasures to promote. J Shanghai Econ Manag Coll 15(2), 36-42 (2017).

6. Johann Sailer. M2M-Internet of Things-Web of Things-Industry 4.0. e \& i Elektrotechnlk und Informationstechnik, 131 (1), 3-4 (2014).

7. CL Yang, China's manufacturing industry development strategy under the background of global "re-industrialization". J Soochow Univ Philos Soc Sci Ed 6, 100-105 (2013).

8. FQ Zhao, ZW Liu. Industrial transformation strategy for the manufacturing sector of China in the tide of industry 4.0. Forum on Science and Technology in China, (1), 58-62 (2016).

\section{Submit your manuscript to a SpringerOpen ${ }^{\circ}$ journal and benefit from:}

- Convenient online submission

- Rigorous peer review

Open access: articles freely available online

- High visibility within the field

- Retaining the copyright to your article 